Article

\title{
Distribution of Relaxation Times and Equivalent Circuits Analysis of $\mathrm{Ba}_{0.5} \mathrm{Sr}_{0.5} \mathrm{Co}_{0.8} \mathrm{Fe}_{0.2} \mathrm{O}_{3-\delta}$
}

\author{
Davide Clematis ${ }^{1}$, Sabrina Presto ${ }^{1, *(\mathbb{D}}$, Maria Paola Carpanese ${ }^{1,2} \mathbb{D}^{\text {, Antonio Barbucci }}{ }^{1,2}$, \\ Francesca Deganello ${ }^{3}$, , Leonarda Francesca Liotta ${ }^{3}$, Chiara Aliotta ${ }^{3}$ and Massimo Viviani ${ }^{1}{ }^{1}$ \\ 1 Consiglio Nazionale delle Ricerche-Istituto di Chimica della Materia Condensata e di Tecnologie per \\ l’Energia (CNR-ICMATE), c/o DICCA-UNIGE, Via all'Opera Pia 15, 16145 Genova, Italy; \\ davide.clematis@ge.icmate.cnr.it (D.C.); carpanese@unige.it (M.P.C.); barbucci@unige.it (A.B.); \\ massimo.viviani@ge.icmate.cnr.it (M.V.) \\ 2 Università di Genova-Dipartimento di Ingegneria Civile, Chimica e Ambientale (UNIGE-DICCA), \\ Via all'Opera Pia 15, 16145 Genova, Italy \\ 3 Consiglio Nazionale delle Ricerche-Istituto per lo Studio dei Materiali Nanostrutturati (CNR-ISMN), \\ Via Ugo La Malfa 153, 90146 Palermo, Italy; francesca.deganello@cnr.it (F.D.); \\ leonardafrancesca.liotta@cnr.it (L.F.L.); chiara.aliotta@ismn.cnr.it (C.A.) \\ * Correspondence: sabrina.presto@ge.icmate.cnr.it
}

Received: 1 April 2019; Accepted: 7 May 2019; Published: 11 May 2019

\begin{abstract}
The phenomena taking place in $\mathrm{Ba}_{0.5} \mathrm{Sr}_{0.5} \mathrm{Co}_{0.8} \mathrm{Fe}_{0.2} \mathrm{O}_{3-\delta}$ (BSCF) as cathodic material in solid oxide fuel cells are investigated by electrochemical impedance spectroscopy. BSCF powders are prepared by solution combustion synthesis. Measurements are collected at different temperatures, under various bias potentials and also recorded after long-term operation. Impedance spectra are thoroughly analyzed by the distribution of relaxation times (DRT) approach and compared to the standard equivalent circuits method. At $700{ }^{\circ} \mathrm{C}$, losses are dominated by ionic conduction and charge transfer at the electrode/electrolyte interface, while oxygen adsorption and bulk diffusion provide a minor contribution to polarization. The performances of pristine materials are remarkable as a very low polarization resistance is measured at $700{ }^{\circ} \mathrm{C}$. After prolonged testing at operative temperature, the BSCF cathodes show increasing total polarization resistance, especially due to progressive limitations in the migration of oxygen ions, caused by secondary phase formation. DRT analysis supports the physical interpretation of phenomena taking place in the material and shows the formation of a new contribution at low frequency which can be ascribed to partial decomposition of BSCF.
\end{abstract}

Keywords: SOFC; DRT; BSCF; cathode; EIS

\section{Introduction}

Solid oxide fuel cells (SOFCs) have been developed for several decades as a power production technology [1]. More recently, their suitability in "power to gas" or "power to chemicals" processes as efficient energy converters was pointed out in several studies addressing the need to store/convert peak and intermittent energy production from renewable sources [2,3]. For these reasons, scientific and technological development of SOFCs is still highly pursued, aiming to better cell architectures and materials, among other aspects. Standard SOFCs are configured as anode-supported cells, but lots of work is being dedicated to metal-supported [4], protonic [5], and dual cells [6,7].

Regardless of the architecture, the cathode is the major source of energy losses, due to limited activity towards the oxygen reduction reaction (ORR), deriving from intrinsic electrocatalytic properties of active materials as well as from the microstructure [8-10]. 
State of the art cathodes are made of an oxide ion conductor, typically doped ceria, and a mixed ionic-electronic conductor, like $(\mathrm{La}, \mathrm{Sr})(\mathrm{Co}, \mathrm{Fe}) \mathrm{O}_{3}$ with perovskite structure (LSCF). A number of alternative compositions have been proposed to reduce the polarization losses of SOFC cathodes, including Ba-based perovskites, like $\mathrm{Ba}_{0.5} \mathrm{Sr}_{0.5} \mathrm{Co}_{0.8} \mathrm{Fe}_{0.2} \mathrm{O}_{3-\delta}$ (BSCF) [11-13]. This material has shown high efficiency thanks to the possibility to stabilize oxygen vacancies at a high concentration within its structure. Oxygen stoichiometry is also believed to influence the electronic properties of BSCF, as metallic behavior was reported for heavily oxidized material [14]. However, structural instability has been thoroughly reported at temperatures of interest for SOFCs, i.e., in the range $600-800{ }^{\circ} \mathrm{C}$, resulting in the formation of a hexagonal structure with a similar composition but poor conductivity and, sometimes, also associated with the formation of other oxides, like $\mathrm{CoO}$ and $\mathrm{Ba}_{0.4} \mathrm{Sr}_{0.6} \mathrm{O}[15,16]$. The phase transition is believed to be related to the oxidation and spin-state transition of Co ions, which are characterized by slow kinetics; for this reason, a progressive deterioration of performance is observed in BSCF cathodes over many hundreds of hours [17]. The detailed mechanism was elucidated by a series of studies, combining several analysis techniques and first principles calculations [18-21]. In summary, if the Fermi level is located at a $\mathrm{Co}-\mathrm{O}$ band, any variation in the concentration of oxygen vacancies will affect the electron configuration of the Co ions [22]. Therefore, when the temperature is raised, e.g., during sintering, oxygen is released from structure and electrons are accumulated in the Co band (Co reduction). On the contrary, when BSCF is equilibrated at intermediate temperatures, oxygen is incorporated again, its band occupancy increases as well as the valence of $\mathrm{Co}$. The first consequence is the quick formation of an intermediate phase, characterized by a stacked sequence of layers with cubic or hexagonal structure and by barium cobaltites with various stoichiometries. Grains of this phase have plate-like shape and composition similar to that of BSCF, with some enrichment in Co.

The plate-like phase is preferentially formed at grain boundaries and at the surface of $\mathrm{CoO}$ particles, if present. After $50-100 \mathrm{~h}$ of equilibration at $\mathrm{T}=700-800^{\circ} \mathrm{C}$, the plate-like phase transforms into the hexagonal one, which is believed to be detrimental for oxide ionic conduction [23].

Reactivity of BSCF with $\mathrm{CO}_{2}$ has also been investigated in order to explain the conductivity drop in gas separation membranes and fuel cells when $\mathrm{CO}_{2}$ is employed as a sweep gas. Formation of carbonates at the surface was observed when exposing BSCF to $1 \%$ of $\mathrm{CO}_{2}$ at low temperature $\left(450{ }^{\circ} \mathrm{C}\right)$ [24].

Impedance spectroscopy is a powerful tool routinely employed to study polarization phenomena in SOFC electrodes. Extraction of information needs processing of impedance spectra, which can be carried out at various levels of precision and complexity. For a rough global description of the system, complex impedance $(Z)$ data are arranged into Nyquist (-ImZ vs. ReZ) or spectroscopic (ReZ vs. f or - ImZ vs. f) Bode plots and visual or graphical inspection is carried out. For more detailed analysis, fitting data to a model impedance function corresponding to a linear combination of ideal equivalent circuits (EqC) is applied [25]. The EqC method allows for easy assignment of various parts of the spectra to different microscopic phenomena, provided that a reliable physical model is available for the system under study. In order to analyze data without the need of underlying models, a different approach can be used, based on the determination of a distribution function of relaxation times (RTs) which completely describes the system [26]. The distribution function can be obtained by solving an equation of the type:

$$
Z\left(\omega_{i}\right)=R_{\infty}+R_{p} \int_{-\infty}^{+\infty} \frac{G(\tau)}{j \omega_{i}} d \ln (\tau)
$$

where $Z\left(\omega_{i}\right)$ are the impedance experimental data, $R_{\infty}$ is the resistance at high frequency, $R_{p}$ is the polarization resistance, and $G(\tau)$ is a normalized function:

$$
\int_{-\infty}^{+\infty} \frac{G(\tau)}{j \omega_{i}} d \ln (\tau)=1
$$


This is an ill-posed inverse problem and many different solutions $(G(\tau))$ are possible. In addition, the solution might be unstable so that different approaches for the regularization are available in the literature [27]. DRT analysis is generally useful to evaluate time constants of main phenomena taking place in the system but can also be considered as a tool to help finding an equivalent circuit that can be used to fit impedance.

In previous works, some of the authors investigated the stability of BSCF cathodes both under different cathodic polarization conditions and for long operation at open circuit voltage (OCV) conditions, reporting the formation of the hexagonal phase and an increasing total polarization resistance with time [28,29].

In this work, some experimental data about BSCF cathodes are presented and analyzed by both the EqC and the DRT methods, in order to get insight into the degradation of this material over $250 \mathrm{~h}$ of operation and to make a comparison between the two methods of analysis of impedance data.

\section{Results}

XRD characterization of as-combusted powders showed the presence of carbonates, spinel phase, and some Co in metallic state, without any detectable amount of the perovskite. After calcination at $950{ }^{\circ} \mathrm{C}$, the abovementioned mixture was completely converted into the cubic $(\mathrm{Pm}-3 \mathrm{~m})$ perovskite phase (ICDD, 109462). More details are reported elsewhere [28,30].

The microstructure of a BSCF cathode is presented in Figure 1, both as-sintered and after electrochemical testing. The as-sintered layer is characterized by large pores, in the $10 \mu \mathrm{m}$ range, quite homogenously distributed in the whole volume. Some submicron particles are present at the surface of the grains, which were already reported in BSCF powders prepared by combustion synthesis and calcined at $950{ }^{\circ} \mathrm{C}$ [30]. Some modifications appear at the surface of grains, where acicular particles are formed. Such structures are reported as a hexagonal phase with composition $\mathrm{Ba}_{0.75} \mathrm{Sr}_{0.25} \mathrm{CoO}_{3}$ [28] and originating from the decomposition of cubic BSCF taking place at temperatures below $800{ }^{\circ} \mathrm{C}$ [31].

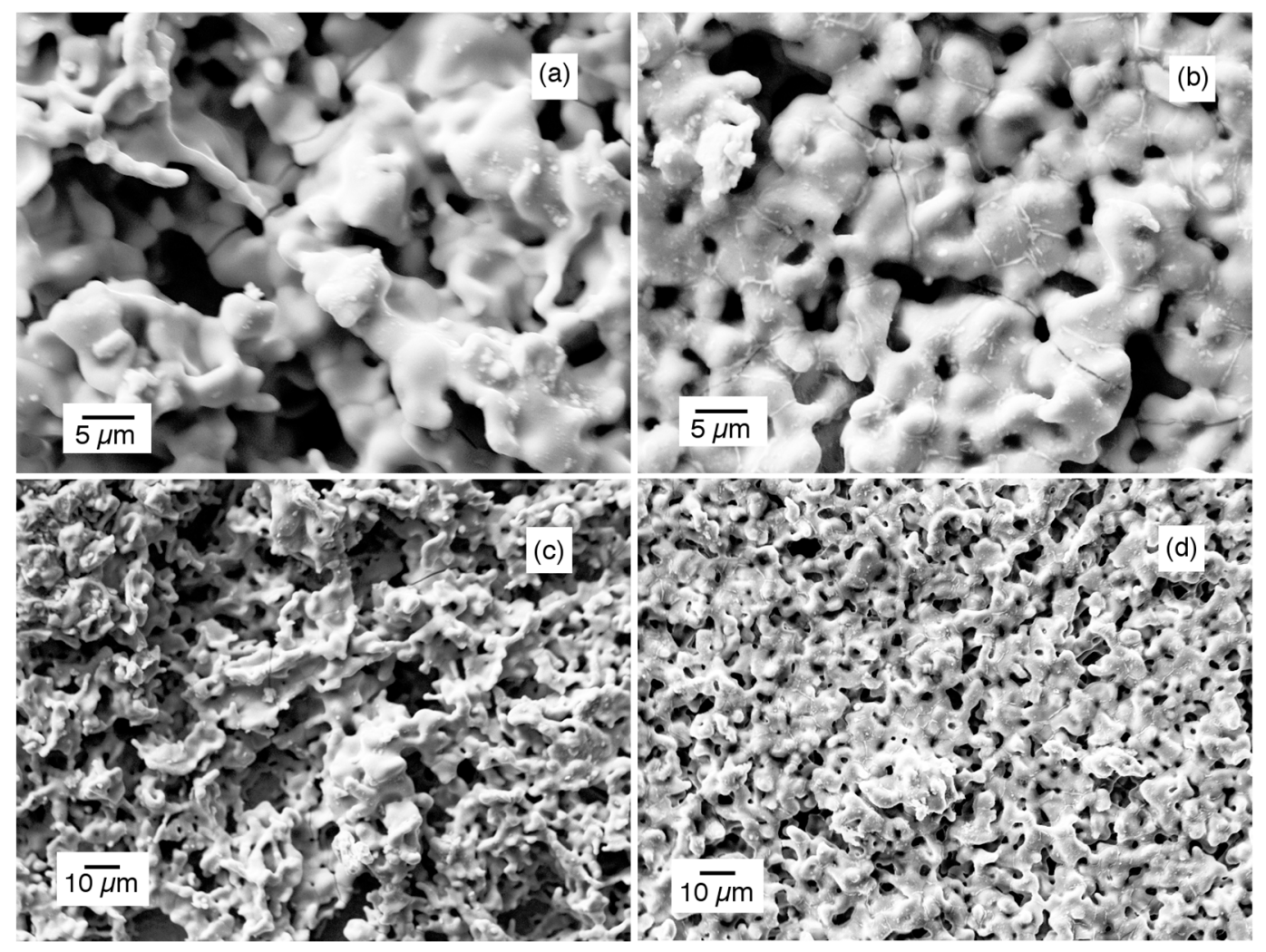

Figure 1. SEM images of the surface of a $\mathrm{Ba}_{0.5} \mathrm{Sr}_{0.5} \mathrm{Co}_{0.8} \mathrm{Fe}_{0.2} \mathrm{O}_{3-\delta}$ (BSCF) cathode as sintered (a,c) and after electrochemical testing $(\mathbf{b}, \mathbf{d})$. 
Impedance data collected at $600{ }^{\circ} \mathrm{C}$ and with different cathodic polarization (bias) values are reported in Figure 2 as Bode plots. One major relaxation is visible in the plots as indicated by the broad peak in Figure $2 \mathrm{~b}$ centered at about $1 \mathrm{~Hz}$. The asymmetric shape of this peak suggests the presence of another process with a quite similar time constant. For this reason, data were fitted to an equivalent circuit model composed by a series of three loops, in agreement with previous work on similar systems [28]: a resistance $\left(\mathrm{R}_{0}\right)$, a parallel resistance/constant phase element $\left(\mathrm{R}_{\mathrm{i}} / \mathrm{CPE}\right)$, and a parallel resistance/capacitance $\left(\mathrm{R}_{\mathrm{S}} / \mathrm{C}_{\mathrm{chem}}\right)$.

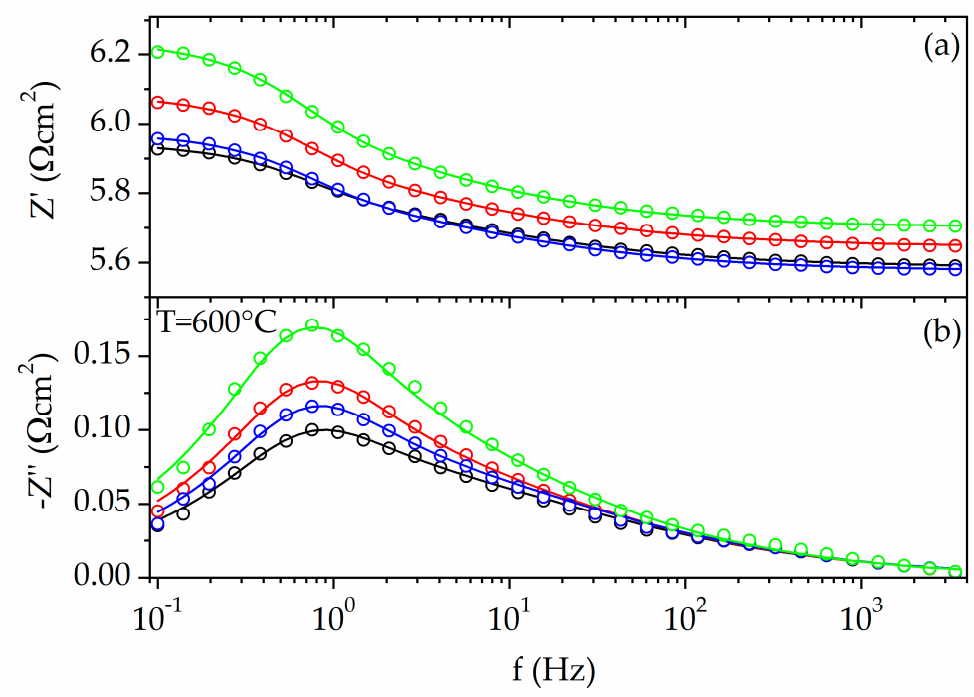

Figure 2. Real (a) and imaginary (b) part of impedance spectra of BSCF at $600{ }^{\circ} \mathrm{C}$ and for various bias levels: black $=0 \mathrm{~V}$, blue $=-0.05 \mathrm{~V}$, red $=-0.1 \mathrm{~V}$, and green $=-0.2 \mathrm{~V}$. Symbols represent experimental data, lines represent the best fit of data obtained by equivalent circuit described in the text.

Impedance measurements were also carried out at $700{ }^{\circ} \mathrm{C}$ under the same conditions and fitted with the same equivalent circuit model. Results are shown in Figure 3, where it is possible to see that, at higher temperature, relaxations are shifted towards higher frequency in comparison with data recorded at $600^{\circ} \mathrm{C}$.

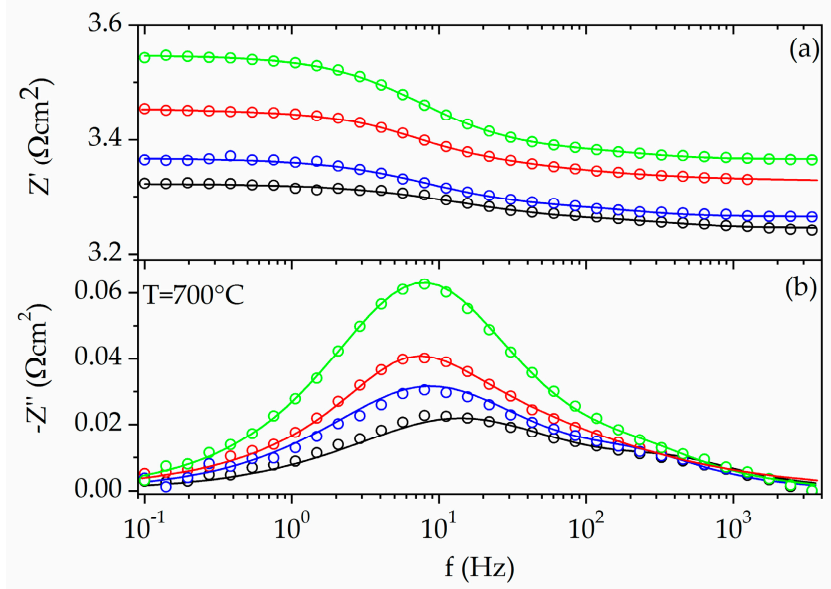

Figure 3. Real (a) and imaginary (b) part of impedance spectra of BSCF at $700{ }^{\circ} \mathrm{C}$ and for various cathodic bias levels: black $=0 \mathrm{~V}$, blue $=-0.05 \mathrm{~V}$, red $=-0.1 \mathrm{~V}$ and green $=-0.2 \mathrm{~V}$. Symbols represent experimental data, lines represent the best fit of data obtained by equivalent circuit described in the text.

From each spectrum at both temperatures and for each bias level, the RT $(\tau)$ of each reactive loop was obtained by the relation:

$$
\tau=R C,
$$


where, in case of the CPE element, the capacitance $C_{e l}$ is given by

$$
C_{e l}=R_{i}^{\left(\frac{1-n}{n}\right)} Q^{\frac{1}{n}}
$$

and $R_{i}, Q, n$ are the parameters of the $R_{i} / \mathrm{CPE}$ loop.

The DRT analyses carried out on the same abovementioned impedance measurements are reported in Figure 4. The distribution function $G$ is represented vs. frequency $(f)$, which is linked to RT $(\tau)$ by the formula:

$$
\tau=\frac{1}{2 \pi f}
$$

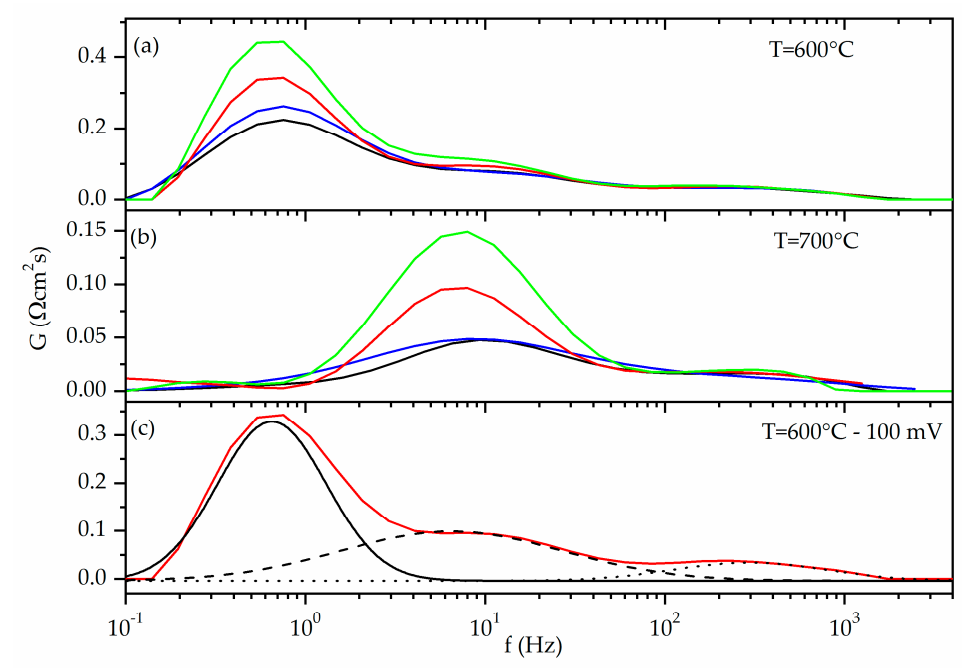

Figure 4. Distribution of relaxation times of BSCF at 600 (a) and $700{ }^{\circ} \mathrm{C}(\mathbf{b})$ for various cathodic bias levels: black $=0 \mathrm{~V}$, blue $=0.05 \mathrm{~V}$, red $=0.1 \mathrm{~V}$ and green $=0.2 \mathrm{~V}$. Distribution of relaxation times (solid red line) and Gaussian model (black solid and dashed lines) utilized for RT calculations (c).

At $600{ }^{\circ} \mathrm{C}$ (Figure 4a), all distribution functions present three peaks, significantly affected by bias potential, except the one at $300 \mathrm{~Hz}$. In raising the temperature to $700{ }^{\circ} \mathrm{C}$ (Figure $4 \mathrm{~b}$ ), the main peak was shifted towards higher frequency, while the one at $300 \mathrm{~Hz}$ was not affected by temperature or by bias potential. The RTs were calculated using Equation (5), after fitting the resolved DRT peaks with Gaussian functions and using the frequency of their maxima as characteristic frequency of each component. An example of fitting with Gaussian components is shown in Figure 4c, where solid, dashed, and dotted black lines refer to the three main contributions to DRT function.

In Figure 5, the comparison among RTs obtained by both EqC and DRT methods is presented. In general, there is a good agreement among the RTs, especially at $600{ }^{\circ} \mathrm{C}$ (Figure $5 \mathrm{a}$ ) in the main component at $\tau \approx 0.2 \mathrm{~s}$. On the contrary, a systematic shift towards lower values is observed in the $\tau$ obtained by DRT for the other component, which is associated with lower resistance (Figure $5 \mathrm{a}$ ). At $700{ }^{\circ} \mathrm{C}$ (Figure $5 \mathrm{~b}$ ), only one component could be resolved by DRT (black points), with an RT close to that of the EqC component at about $0.03 \mathrm{~s}$ (blue points).

The effects of long time permanence at $700{ }^{\circ} \mathrm{C}$ on the electrochemical behavior of BSCF cathodes were also investigated. The results of impedance measurements at various times between 0 and $250 \mathrm{~h}$ are reported in Figure 6a, together with the result of fittings by the EqC method. It can be observed that the relaxation peak is progressively shifted towards lower frequencies and its shape is distorted. This evolution is better highlighted by the DRT analysis, presented in Figure $6 \mathrm{~b}$. 


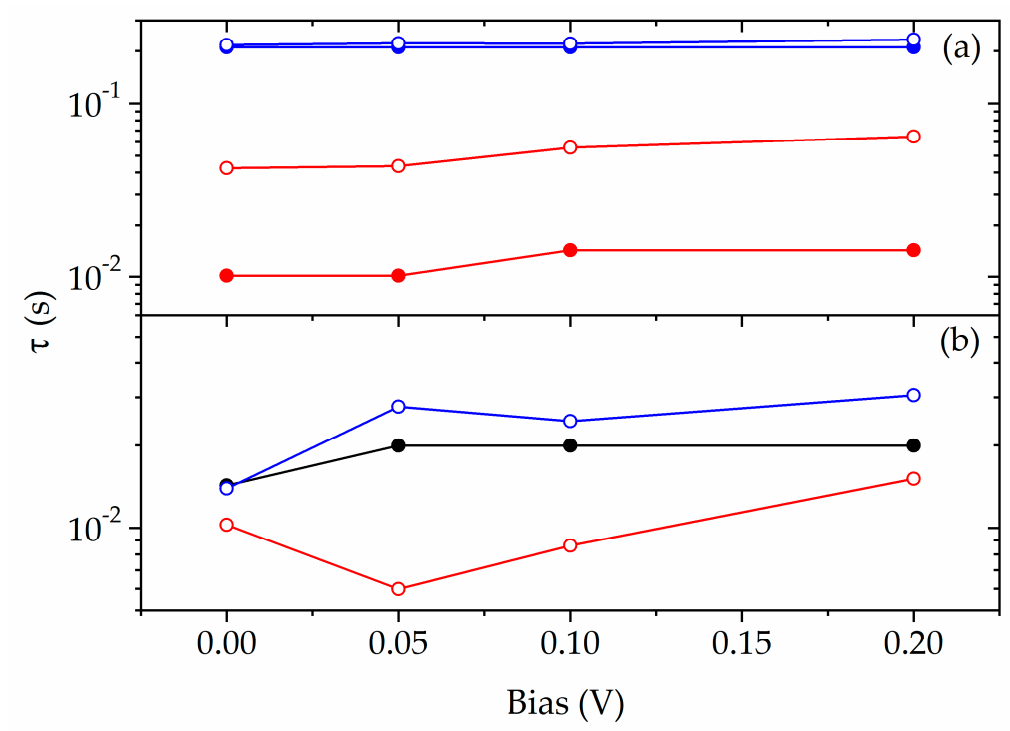

Figure 5. Relaxation times vs. bias of low (blue points) and medium-frequency (red points) contributions, as calculated by distribution of relaxation times (DRT) (full symbols) and equivalent circuits (open symbols) at 600 (a) and $700{ }^{\circ} \mathrm{C}(\mathbf{b})$.

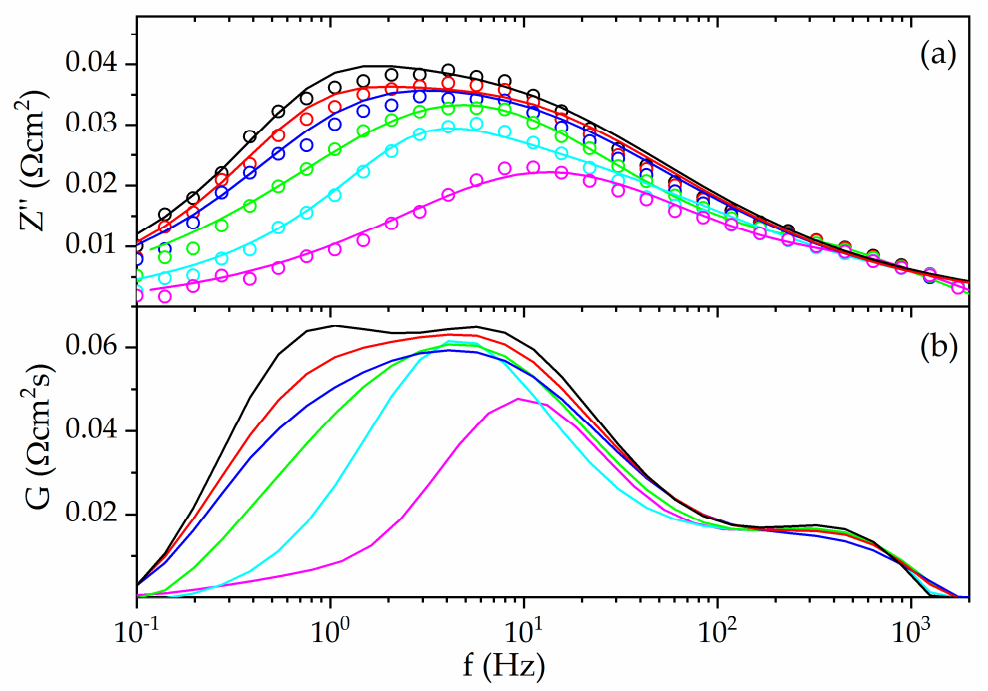

Figure 6. Imaginary part of impedance spectra (a) and distribution of relaxation times (b) at different aging time $\left(\mathrm{T}=700{ }^{\circ} \mathrm{C}\right)$ : magenta $=0 \mathrm{~h}$, cyan $=50 \mathrm{~h}$, green $=100 \mathrm{~h}$, blue $=150 \mathrm{~h}$, red $=200 \mathrm{~h}$, and black $=250 \mathrm{~h}$. In (a) symbols represent experimental data and lines represent the best fit of data obtained by equivalent circuit described in the text.

The apparently single component which is visible at $10 \mathrm{~Hz}$ at the beginning of the test is progressively resolved into two components that appear well separated after $250 \mathrm{~h}$. The RTs obtained for this series of measurements are shown in Figure 7a. During the first $50 \mathrm{~h}$, only one time constant is available from DRT (black points), which is an average of RT extracted from EqC. On the contrary, there is a very good agreement between EqC and DRT after $100 \mathrm{~h}$, i.e. when the DRT starts to be resolved in two components (red and blue points). From the figure, it can be estimated that the RTs of two components need to differ by at least one order of magnitude to be adequately separated in the DRT plot. 


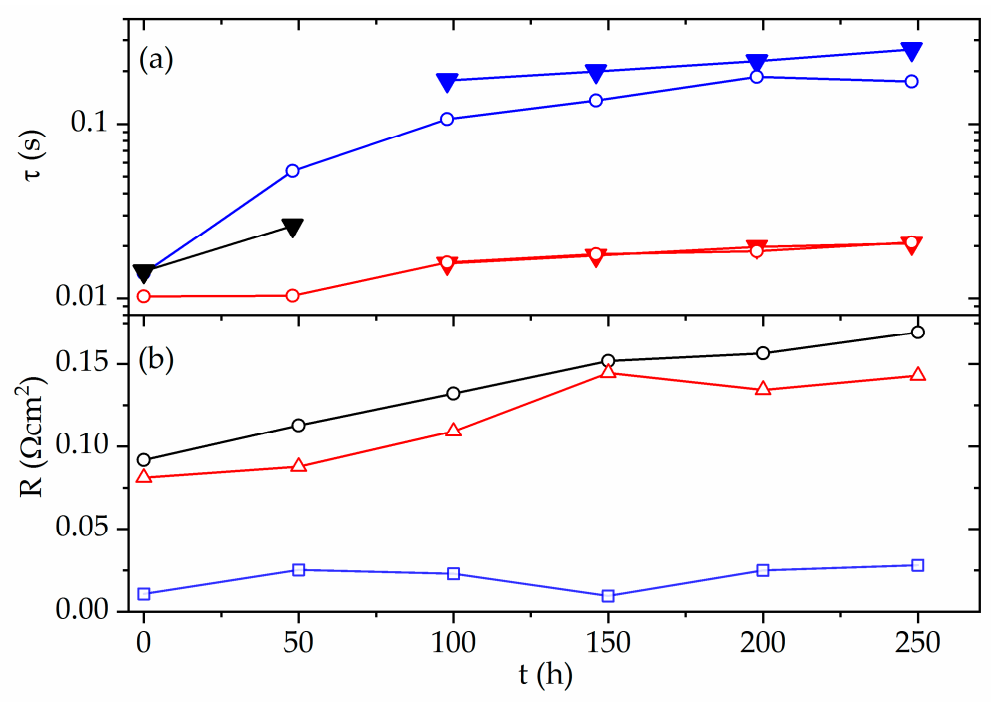

Figure 7. Relaxation times as calculated by DRT (full symbols) and EqC (open symbols) (a) and total polarization (black), Ri (red), and Rs (blue) resistances (b) at different aging times. $\mathrm{T}=700{ }^{\circ} \mathrm{C}$. Discontinuity of DRT in (a) is motivated by time constant closer than one order of magnitude for $\mathrm{t}<100 \mathrm{~h}$.

Figure $7 \mathrm{~b}$ reports the total polarization resistance, which increases all along the duration of the aging, together with $R_{s}$ and $R_{i}$ calculated by the EqC method. It must be pointed out that the main contribution to polarization at long times is due to the component at higher frequency, as indicated by the shape of DRT curves in Figure $6 \mathrm{~b}$ and of Ri in $7 \mathrm{~b}$.

\section{Discussion}

The DRT analysis of impedance spectroscopy data collected on BSCF cathodes was demonstrated to be a useful guide for more detailed analyses to be carried out by using the EqC method. However, DRT results cannot be taken without some critical insight, which is necessary to avoid misinterpretation.

In particular, it is known that when the number of measurements is less than 50-100 points per decade (ppd), some apparent relaxations are present in the distribution function plot of distributed elements. Specifically, when dealing with CPE elements, a small peak at high frequency, approximately 2 orders of magnitudes apart from the main resonant frequency, appears at about $10 \mathrm{ppd}$ [32]. Resolution of multiple time constants is also deeply affected by ppd, requiring a frequency separation larger than one order of magnitude when standard ppd not exceeding 10 is used, due to broadening of the distribution function [32].

Therefore, it can be assumed that the peak at about $300 \mathrm{~Hz}$, which is always present in the DRT plots and is not influenced by operative parameters (time, temperature, and bias voltage), is only due to discretization of impedance data and can be neglected in the discussion of material properties.

From data collected at $600{ }^{\circ} \mathrm{C}$ and at various bias potentials, it looks reasonable to describe the system with two time constants (Figure 4a), i.e., with equivalent circuit with two loops. In Figure 4b, the shape of DRT function does not allow for extraction of two time constants, but for consistency with measurements at lower T, it can be assumed that the RTs are closer than 1 order of magnitude (more precisely, the ratio of larger to lower RT is less than 10). The physical description of the electrochemical behavior of a mixed ionic-electronic cathode on a pure ionic conductor was given, for instance in [33]. The oxygen exchange reaction is well approximated by a $R_{S} / C_{c h e m}$ loop, where the capacitive term is defined "chemical capacitance" and is associated to the volume density of charged point defects, like oxygen vacancies. The second term is also approximated by a $\mathrm{R} / \mathrm{C}$ or $\mathrm{R}_{\mathrm{i}} / \mathrm{CPE}$ and is associated with ionic conduction and charge transfer at electrode-electrolyte interface [28]. The chemical capacitance loop is characterized by larger time constant because is relevant to phenomena taking place at the 
gas-solid interface; consequently, it will be associated with the low-frequency section of the impedance spectrum. RT values presented in Figure 5 are in agreement with abovementioned considerations: two time constants are individuated in the DRT at $600^{\circ} \mathrm{C}$, separated by more than one order of magnitude, which is no longer the case at $700{ }^{\circ} \mathrm{C}$. In fact, at this temperature, the ratio of the two RTs obtained by $\mathrm{EqC}$ ranges between 2 and 4, depending on the bias voltage, and the single DRT time constant is closer to the step with larger resistance, i.e., at the low frequency.

Extending the $700{ }^{\circ} \mathrm{C}$ test up to $250 \mathrm{~h}$ allowed resolving the two time constants, again, because their ratio exceeded 10, starting from about $100 \mathrm{~h}$. Looking at Figure 7a, it is clear that both RTs keep increasing with time but with different rates, with that at low frequency being the fastest.

These analyses indicate that:

i. $\quad$ Oxygen surface exchange is the limiting step in pristine BSCF when $\mathrm{T}<700{ }^{\circ} \mathrm{C}$;

ii. At $700{ }^{\circ} \mathrm{C}$, the surface exchange kinetics, expressed by $R_{s}$, are much faster so that most of losses are due to ionic conduction inside the bulk of the electrode and at the electrode-electrolyte interface.

This is demonstrated by the significant increase of the RT associated to surface reaction and, more clearly, by the comparison of $R_{s}$ with $R_{i}$ shown in Figure $7 b$.

Isothermal operation of the BSCF electrode mainly resulted in an increase of $R_{i}$ along the aging time. The explanation of such behavior can be found in the formation of a secondary phase with poor ionic conductivity which reduces overall conduction, as mentioned in the introduction. This is also in agreement with previous results on samples prepared by the same technique and analyzed by X-ray diffraction after electrochemical tests [28]. This phase decorates grain boundaries, as can be seen in Figure $1 b, d$ and, therefore, affects conductivity. On the contrary, $R_{s}$ remained almost stable, indicating that oxygen surface exchange is not affected by long-term operation, although the significant increase of its time constant (Figure 7a) implies the increase of the associated chemical capacitance. As the $\mathrm{C}_{\text {chem }}$ is proportional to charge stored in form of oxygen vacancies [33], a progressive increase of this quantity would be derived from above considerations. As already mentioned, previous works about BSCF decomposition reported the sluggish formation of secondary phases with hexagonal structure and with general formulae $\mathrm{Ba}_{0.6} \mathrm{Sr}_{0.4} \mathrm{CoO}_{3-\delta}$ or $\mathrm{Ba}_{1-\mathrm{x}} \mathrm{Sr}_{\mathrm{x}} \mathrm{Co}_{2-\mathrm{y}} \mathrm{Fe}_{\mathrm{y}} \mathrm{O}_{5-\delta}$, which leave the parent $\mathrm{BSCF}$ structure with excess $\mathrm{Sr}$ and Fe [31]. The oxygen non-stoichiometry of the cubic-hexagonal mixture is generally lower than that of pure cubic BSCF [17], meaning that phase transition is expected to reduce oxygen vacancies concentration. In order to rationalize the opposite behavior found here, it can be noted that impedance is sensitive to series combination only, meaning that if the secondary phases are organized as isolated domains, then low-frequency impedance, in particular, will be scarcely affected by their presence. Therefore, oxygen non-stoichiometry contributing to $\mathrm{C}_{\text {chem }}$ is that of a cubic BSCF, possibly increased by an excess of $\mathrm{Sr}$ and Fe. The overall impact of secondary phases formation is negative in any case, because of their reduced ionic conductivity.

\section{Materials and Methods}

BSCF powders were prepared by solution combustion synthesis starting from a sucrose (Eridania Italia S.p.A., Bologna, Italy) and polyethylene glycol (PEG, MW 20000, purum Fluka Chemie, GmbH, Buchs, Switzerland) fuel mixture. $\mathrm{Ba}\left(\mathrm{NO}_{3}\right)_{2}(99.1 \%$ WWR International, Fontenay-sous-Bois, France), $\mathrm{Sr}\left(\mathrm{NO}_{3}\right)_{2}\left(\geq 99.97 \%\right.$ Alfa Aesar $\mathrm{GmbH} \& \mathrm{Co} \mathrm{KG}$, Karlsruhe, Germany), $\mathrm{Co}\left(\mathrm{NO}_{3}\right)_{2} \cdot 6 \mathrm{H}_{2} \mathrm{O}(99.0 \%$ Fluka-Sigma-Aldrich Chemie $\mathrm{GmbH}$, Steinheim, Germany) and $\mathrm{Fe}\left(\mathrm{NO}_{3}\right)_{3} \cdot 9 \mathrm{H}_{2} \mathrm{O}(99.95 \%$ Sigma-Aldrich Chemie, $\mathrm{GmbH}$, Schnelldorf; Germany) as metal precursors were intimately mixed with the fuel. The sucrose-to-metal cations and the reducer-to-oxidizer molar ratios were set at 2 and 3.1, respectively, by adding proper amounts of fuel mixture and $\mathrm{NH}_{4} \mathrm{NO}_{3}(\geq 99.5 \%$ BioXtra-Sigma-Aldrich Chemie, $\mathrm{GmbH}$, Schnelldorf, Germany). 
Mixtures were kept at $80^{\circ} \mathrm{C}$, under stirring, in order to form a gel, and then heated on a hot plate to initiate the combustion. The resulting black powder was eventually calcined in air at $950{ }^{\circ} \mathrm{C}$ for $5 \mathrm{~h}$ to allow for crystallization of desired phase.

Electrolyte-supported half-cells were prepared, starting from $\mathrm{Ce}_{0.8} \mathrm{Sm}_{0.2} \mathrm{O}_{2-\delta}$ powder (SDC20-HP, Fuel Cell Materials). For each electrolyte support, $6.5 \mathrm{~g}$ of powder was weighed out and cold-pressed at $60 \mathrm{MPa}$. After sintering at $1500{ }^{\circ} \mathrm{C}$ for $5 \mathrm{~h}$ in air, SDC disk-shaped pellets with a diameter of $25 \mathrm{~mm}$ and a thickness of $1.2 \mathrm{~mm}$ were obtained. The electrodes were prepared as follows: the BSCF powder was mixed with alpha-terpineol (Sigma-Aldrich) and manually ground in a mortar, to form a paste suitable to be slurry-coated on the SDC surfaces. Two symmetrical circular electrodes, acting as the working and the counter electrode (WE and CE, respectively), were obtained. A ring-shaped electrode (1 mm wide) made of the same BSCF mixture was deposited around the WE at a distance equal to three-times the electrolyte thickness, to be used as reference electrode (RE) in the three-electrode configuration measurements [34]. Surfaces of the electrolytes were scraped before electrode deposition in order to improve adhesion. After sintering at $1100{ }^{\circ} \mathrm{C}$ for $2 \mathrm{~h}$, the thickness of WE and CE was $20 \mu \mathrm{m}$ while their apparent geometric area was $0.28 \mathrm{~cm}^{2}$.

The phase composition of powders and ceramics was analyzed by X-ray diffraction (XRD, D5000 Siemens-Bruker AXS Inc., Berlin, Germany)) and detailed results are reported in [28], while the microstructure was determined by scanning electron microscopy (SEM, LEO 1450vp, Carl Zeiss Jena $\mathrm{GmbH}$, Oberkochen , Germany) and energy dispersive X-ray spectroscopy (EDX, Oxford Instruments, Abingdon-on-Thames, UK).

The electrochemical behavior of the cathode/electrolyte system was investigated through impedance spectroscopy, placing the cell inside a home-designed test station, connected to a potentiostat coupled to a frequency response analyzer (PGSTAT302N, Metrohom Autolab B.V., Utrecht, NL). Different cathodic overpotentials (from 0.05 to $0.2 \mathrm{~V}$ ) were superimposed to the perturbation voltage (amplitude $20 \mathrm{mV}, 8$ points per decade) to check the redox behavior of the system and to get information in real operating conditions. A Pt net was placed both on the WE and on the CE to collect the current, while three-electrode impedances (using a RE) were extracted. Impedance spectra were analyzed by the equivalent circuit fitting method (ZView, Scribner Associates) and by the distribution of relaxation times (DRT) approach.

In this paper, the DRT technique was applied following Ciucci group's approach and tool [35].

\section{Conclusions}

The combustion synthesis allowed for the preparation of $\mathrm{B}_{0.5} \mathrm{~S}_{0.5} \mathrm{C}_{0.8} \mathrm{~F}_{0.2} \mathrm{O}_{3-\delta}$ powders that can be used to fabricate air electrodes in SOFCs. The performances of pristine materials are remarkable as a very low polarization resistance was measured at $700{ }^{\circ} \mathrm{C}$. After prolonged testing at operative temperature, the BSCF cathodes showed increasing total polarization resistance, due especially to progressive limitations in the migration of oxygen ions that was caused by secondary phase formation. DRT analysis supported the physical interpretation of phenomena taking place in the material by suggesting the presence of two main time constants associated either to oxygen surface exchange or to charge transfer at the electrode-electrolyte interface.

Author Contributions: Conceptualization, S.P., M.P.C. and F.D.; Formal analysis, D.C. and S.P.; Investigation, S.P., M.P.C. and C.A.; Visualization, S.P.; Writing—original draft, M.V.; Writing-review \& editing, D.C., S.P., M.P.C., A.B., F.D., L.F.L. and C.A.

Funding: This research received no external funding.

Conflicts of Interest: The authors declare no conflict of interest.

\section{References}

1. Ramadhani, F.; Hussain, M.A.; Mokhlis, H.; Hajimolana, S. Optimization strategies for Solid Oxide Fuel Cell (SOFC) application: A literature survey. Renew. Sustain. Energy Rev. 2017, 76, 460-484. [CrossRef] 
2. Götz, M.; Lefebvre, J.; Mörs, F.; McDaniel Koch, A.; Graf, F.; Bajohr, S.; Reimert, R.; Kolb, T. Renewable Power-to-Gas: A technological and economic review. Renew. Energy 2016, 85, 1371-1390. [CrossRef]

3. Marrony, M.; Dailly, J. Advanced Proton Conducting Ceramic Cell as Energy Storage Device. J. Electrochem. Soc. 2017, 164, F988-F994. [CrossRef]

4. Presto, S.; Barbucci, A.; Carpanese, M.; Han, F.; Costa, R.; Viviani, M. Application of La-Doped $\mathrm{SrTiO}_{3}$ in Advanced Metal-Supported Solid Oxide Fuel Cells. Crystals 2018, 8, 134. [CrossRef]

5. Mahadik, P.S.; Shirsat, A.N.; Saha, B.; Sitapure, N.; Tyagi, D.; Varma, S.; Wani, B.N.; Bharadwaj, S.R. Chemical compatibility study of BSCF cathode materials with proton-conducting BCY/BCZY/BZY electrolytes. J. Therm. Anal. Calorim. 2019, 2. [CrossRef]

6. Presto, S.; Barbucci, A.; Viviani, M.; Ilhan, Z.; Ansar, A.; Soysal, D.; Thorel, A.S.; Abreu, J.; Chesnaud, A.; Politova, T.; et al. IDEAL-Cell, Innovative Dual mEmbrAne fueL-Cell: Fabrication and Electrochemical Testing of First Prototypes. ECS Trans. 2009, 25, 773-782.

7. Thorel, A.S.; Abreu, J.; Ansar, S.A.; Barbucci, A.; Brylewski, T.; Chesnaud, A.; Ilhan, Z.; Piccardo, P.; Prazuch, J.; Presto, S.; et al. Proof of Concept for the Dual Membrane Cell: I. Fabrication and Electrochemical Testing of First Prototypes. J. Electrochem. Soc. 2013, 160, F360-F366. [CrossRef]

8. Fleig, J. Solid Oxide Fuel Cell Cathodes: Polarization Mechanisms and Modeling of the Electrochemical Performance. Annu. Rev. Mater. Res. 2003, 33, 361-382. [CrossRef]

9. Nicolella, C.; Bertei, A.; Viviani, M.; Barbucci, A. Morphology and electrochemical activity of SOFC composite cathodes: II. Mathematical modelling. J. Appl. Electrochem. 2009, 39, 503-511. [CrossRef]

10. Barbucci, A.; Viviani, M.; Panizza, M.; Delucchi, M.; Cerisola, G. Analysis of the oxygen reduction process on SOFC composite electrodes. J. Appl. Electrochem. 2005, 35, 399-403. [CrossRef]

11. da Silva, F.S.; de Souza, T.M. Novel materials for solid oxide fuel cell technologies: A literature review. Int. J. Hydrogen Energy 2017, 42, 26020-26036. [CrossRef]

12. Giuliano, A.; Carpanese, M.P.; Panizza, M.; Cerisola, G.; Clematis, D.; Barbucci, A. Characterisation of $\mathrm{La}_{0.6} \mathrm{Sr}_{0.4} \mathrm{Co}_{0.2} \mathrm{Fe}_{0.8} \mathrm{O}_{3-\delta}-\mathrm{Ba}_{0.5} \mathrm{Sr}_{0.5} \mathrm{Co}_{0.8} \mathrm{Fe}_{0.2} \mathrm{O}_{3-\delta}$ composite as cathode for solid oxide fuel cells. Electrochim. Acta 2017, 240, 258-266. [CrossRef]

13. Bertei, A.; Barbucci, A.; Carpanese, M.P.; Viviani, M.; Nicolella, C. Morphological and electrochemical modeling of SOFC composite cathodes with distributed porosity. Chem. Eng. J. 2012, 207-208, 167-174. [CrossRef]

14. Yamada, I.; Odake, T.; Asai, K.; Oka, K.; Kawaguchi, S.; Wada, K.; Yagi, S. High-pressure synthesis of highly oxidized $\mathrm{Ba}_{0.5} \mathrm{Sr}_{0.5} \mathrm{Co}_{0.8} \mathrm{Fe}_{0.2} \mathrm{O}_{3-\delta}$ cubic perovskite. Mater. Chem. Front.. [CrossRef]

15. Brisotto, M.; Cernuschi, F.; Drago, F.; Lenardi, C.; Rosa, P.; Meneghini, C.; Merlini, M.; Rinaldi, C. High temperature stability of $\mathrm{Ba}_{0.5} \mathrm{Sr}_{0.5} \mathrm{Co}_{0.8} \mathrm{Fe}_{0.2} \mathrm{O}_{3-\delta}$ and $\mathrm{La}_{0.6} \mathrm{Sr}_{0.4} \mathrm{Co}_{1-\mathrm{y}} \mathrm{FeyO}_{3-\delta}$ oxygen separation perovskite membranes. J. Eur. Ceram. Soc. 2016, 36, 1679-1690. [CrossRef]

16. Yaremchenko, A.A.; Patrakeev, M.V.; Naumovich, E.N.; Khalyavin, D.D. The p (O2)-T stability domain of cubic perovskite $\mathrm{Ba}_{0.5} \mathrm{Sr}_{0.5} \mathrm{Co}_{0.8} \mathrm{Fe}_{0.2} \mathrm{O}_{3-\delta}$. Phys. Chem. Chem. Phys. 2018, 20, 4442-4454. [CrossRef] [PubMed]

17. Svarcova, S.; Wiik, K.; Tolchard, J.; Bouwmeester, H.J.M.; Grande, T. Structural instability of cubic perovskite $\mathrm{BaxSr}_{1-\mathrm{x}} \mathrm{Co}_{1-\mathrm{y}} \mathrm{Fe}_{\mathrm{y}} \mathrm{O}_{3-\delta}$. Solid State Ionics 2008, 178, 1787-1791. [CrossRef]

18. Unger, L.-S.; Niedrig, C.; Wagner, S.F.; Menesklou, W.; Baumann, S.; Meulenberg, W.A.; Ivers-Tiffée, E. Yttrium doping of $\mathrm{Ba}_{0.5} \mathrm{Sr}_{0.5} \mathrm{Co}_{0.8} \mathrm{Fe}_{0.2} \mathrm{O}_{3-\delta}$ part I: Influence on oxygen permeation, electrical properties, reductive stability, and lattice parameters. J. Eur. Ceram. Soc. 2018, 38, 2378-2387. [CrossRef]

19. Unger, L.-S.; Ruhl, R.; Meffert, M.; Niedrig, C.; Menesklou, W.; Wagner, S.F.; Gerthsen, D.; Bouwmeester, H.J.M.; Ivers-Tiffée, E. Yttrium doping of $\mathrm{Ba}_{0.5} \mathrm{Sr}_{0.5} \mathrm{Co}_{0.8} \mathrm{Fe}_{0.2} \mathrm{O}_{3-\delta}$ part II: Influence on oxygen transport and phase stability. J. Eur. Ceram. Soc. 2018, 38, 2388-2395. [CrossRef]

20. Müller, P.; Störmer, H.; Dieterle, L.; Niedrig, C.; Ivers-Tiffée, E.; Gerthsen, D. Decomposition pathway of cubic $\mathrm{Ba}_{0.5} \mathrm{Sr}_{0.5} \mathrm{Co}_{0.8} \mathrm{Fe}_{0.2} \mathrm{O}_{3-\delta}$ between $700{ }^{\circ} \mathrm{C}$ and $1000{ }^{\circ} \mathrm{C}$ analyzed by electron microscopic techniques. Solid State Ionics 2012, 206, 57-66. [CrossRef]

21. Müller, P.; Störmer, H.; Meffert, M.; Dieterle, L.; Niedrig, C.; Wagner, S.F.; Ivers-Tiffée, E.; Gerthsen, D. Secondary Phase Formation in $\mathrm{Ba}_{0.5} \mathrm{Sr}_{0.5} \mathrm{Co}_{0.8} \mathrm{Fe}_{0.2} \mathrm{O}_{3-\mathrm{d}}$ Studied by Electron Microscopy. Chem. Mater. 2013, 25, 564-573. [CrossRef] 
22. Merkle, R.; Mastrikov, Y.A.; Kotomin, E.A.; Kuklja, M.M.; Maier, J. First Principles Calculations of Oxygen Vacancy Formation and Migration in $\mathrm{Ba}_{1-x} \mathrm{Sr}_{x} \mathrm{Co}_{1-y} \mathrm{Fe}_{y} \mathrm{O}_{3-\delta}$ Perovskites. J. Electrochem. Soc. 2011, 159, B219-B226. [CrossRef]

23. Meffert, M.; Unger, L.-S.; Störmer, H.; Sigloch, F.; Wagner, S.F.; Ivers-Tiffée, E.; Gerthsen, D. The effect of B-site Y substitution on cubic phase stabilization in $\left(\mathrm{Ba}_{0.5} \mathrm{Sr}_{0.5}\right)\left(\mathrm{Co}_{0.8} \mathrm{Fe}_{0.2}\right) \mathrm{O}_{3-\delta}$. J. Am. Ceram. Soc. 2019, 1-14.

24. Yan, A.; Maragou, V.; Aricò, A.; Cheng, M.; Tsiakaras, P. Investigation of a $\mathrm{Ba}_{0.5} \mathrm{Sr}_{0.5} \mathrm{Co}_{0.8} \mathrm{Fe}_{0.2} \mathrm{O}_{3-\delta}$ based cathode SOFC. Appl. Catal. B Environ. 2007, 76, 320-327. [CrossRef]

25. Barsoukov, E.; Macdonald, J.R. Impedance Spectroscopy. Theory, Experiment, and Applications, 2nd ed.; Barsukov, E., Macdonald, J.R., Eds.; Wiley-Interscience: Hoboken, NJ, USA, 2005; ISBN 0-471-64749-7.

26. Boukamp, B.A.; Rolle, A. Use of a distribution function of relaxation times (DFRT) in impedance analysis of SOFC electrodes. Solid State Ionics 2018, 314, 103-111. [CrossRef]

27. Schichlein, H.; Müller, A.C.; Voigts, M.; Krügel, A.; Ivers-Tiffée, E. Deconvolution of electrochemical impedance spectra for the identification of electrode reaction mechanisms in solid oxide fuel cells. J. Appl. Electrochem. 2002, 32, 875-882. [CrossRef]

28. Giuliano, A.; Carpanese, M.P.; Clematis, D.; Boaro, M.; Pappacena, A.; Deganello, F.; Liotta, L.F.; Barbucci, A. Infiltration, Overpotential and Ageing Effects on Cathodes for Solid Oxide Fuel Cells: $\mathrm{La}_{0.6} \mathrm{Sr}_{0.4} \mathrm{Co}_{0.2} \mathrm{Fe}_{0.8} \mathrm{O}_{3-\delta}$ versus $\mathrm{Ba}_{0.5} \mathrm{Sr}_{0.5} \mathrm{Co}_{0.8} \mathrm{Fe}_{0.2} \mathrm{O}_{3-\delta}$. J. Electrochem. Soc. 2017, 164, F3114-F3122. [CrossRef]

29. Carpanese, M.P.; Clematis, D.; Viviani, M.; Presto, S.; Panizza, M.; Cerisola, G.; Barbucci, A. Characterisation of $\mathrm{La}_{0.6} \mathrm{Sr}_{0.4} \mathrm{Co}_{0.2} \mathrm{Fe}_{0.8} \mathrm{O}_{3-\delta}-\mathrm{Ba}_{0.5} \mathrm{Sr}_{0.5} \mathrm{Co}_{0.8} \mathrm{Fe}_{0.2} \mathrm{O}_{3-\delta}$ composite as cathode for solid oxide fuel cells. Bulg. Chem. Commun. 2018, 50, 95-101.

30. Deganello, F.; Liotta, L.F.; Marcì, G.; Fabbri, E.; Traversa, E. Strontium and iron-doped barium cobaltite prepared by solution combustion synthesis: Exploring a mixed-fuel approach for tailored intermediate temperature solid oxide fuel cell cathode materials. Mater. Renew. Sustain. Energy 2013, 2, 8. [CrossRef]

31. Efimov, K.; Xu, Q.; Feldhoff, A. Transmission Electron Microscopy Study of $\mathrm{Ba}_{0.5} \mathrm{Sr}_{0.5} \mathrm{Co}_{0.8} \mathrm{Fe}_{0.2} \mathrm{O}_{3-\delta}$ Perovskite Decomposition at Intermediate Temperatures. Chem. Mater. 2010, 22, 5866-5875. [CrossRef]

32. Zhang, Y.; Chen, Y.; Yan, M.; Chen, F. Reconstruction of relaxation time distribution from linear electrochemical impedance spectroscopy. J. Power Sources 2015, 283, 464-477. [CrossRef]

33. Jamnik, J.; Maier, J. Generalised equivalent circuits for mass and charge transport: Chemical capacitance and its implications. Phys. Chem. Chem. Phys. 2001, 3, 1668-1678. [CrossRef]

34. Raikova, G.; Carpanese, P.; Stoynov, Z.; Vladikova, D.; Viviani, M.; Barbucci, A. Inductance correction in impedance studies of solid oxide fuel cells. Bulg. Chem. Commun. 2009, 41, 199-206.

35. Wan, T.H.; Saccoccio, M.; Chen, C.; Ciucci, F. Influence of the Discretization Methods on the Distribution of Relaxation Times Deconvolution: Implementing Radial Basis Functions with DRTtools. Electrochim. Acta 2015, 184, 483-499. [CrossRef]

(C) 2019 by the authors. Licensee MDPI, Basel, Switzerland. This article is an open access article distributed under the terms and conditions of the Creative Commons Attribution (CC BY) license (http://creativecommons.org/licenses/by/4.0/). 